\title{
Invited review: The anti-inflammatory properties of dairy lipids
}

\author{
R. Lordan and I. Zabetakis ${ }^{1}$ \\ Department of Biological Sciences, University of Limerick, Limerick, Ireland
}

\begin{abstract}
Dairy product consumption is often associated with negative effects because of its naturally high levels of saturated fatty acids. However, recent research has shown that dairy lipids possess putative bioactivity against chronic inflammation. Inflammation triggers the onset of several chronic diseases, including cardiovascular disease, type 2 diabetes mellitus, obesity, and cancer. This review discusses the anti-inflammatory properties of dairy lipids found in milk, yogurt, and cheese, and it examines them in relation to their implications for human health: their protective effects and their role in pathology. We also consider the effect of lipid profile alteration in dairy products - by using ruminant dietary strategies to enrich the milk, or by lipid fortification in the products. We critically review the in vivo, in vitro, ex vivo, and epidemiological studies associated with these dairy lipids and their role in various inflammatory conditions. Finally, we discuss some suggestions for future research in the study of bioactive lipids and dairy products, with reference to the novel field of metabolomics and epidemiological studies.
\end{abstract}

Key words: inflammation, cardiovascular disease, lipids, dairy

\section{INTRODUCTION}

Increasing evidence supports the pivotal function of nutrition in the development of chronic diseases such as cardiovascular disease (CVD), cancer, insulin resistance, and obesity (Shingfield et al., 2008; Mozaffarian et al., 2011). In the public and scientific domains, people see dairy fat as a negative component of milk and dairy products, predominantly because they are energy-dense, rich in cholesterol and saturated fat (Kratz et al., 2013). Dairy products are conventionally perceived as having an adverse effect on health (Risérus et al., 2009), particularly in relation to CVD, which is a leading cause of death in developed societies due to

Received October 28, 2016.

Accepted February 2, 2017.

${ }^{1}$ Corresponding author: Ioannis.Zabetakis@ul.ie factors such as diet, stress, obesity, sedentary lifestyle, type 2 diabetes, and smoking, among others (Siurana and Calsamiglia, 2016). In this review, we discuss the nutritional value of the lipid components of milk and dairy products to highlight the anti-inflammatory activities of lipids such as CLA, PUFA, and polar lipids.

\section{THE BIOCHEMISTRY OF INFLAMMATION}

Inflammation is a necessary process of the innate immune system and is required for physiological responses such as initiating tissue repair and eliminating pathogenic insults, but excessive inflammation can lead to tissue injury (Salajegheh, 2016). Inflammation is a complex biological process that involves numerous interactions between different cell types, as well as the production of and responses to several chemical mediators (Calder et al., 2011). It is an integral feature of atherosclerosis, CVD, cancer, type 2 diabetes, obesity, and even Alzheimer's disease (Ross, 1999; Libby et al., 2002; Tselepis and Chapman, 2002; Greenberg and Obin, 2006; Reuter et al., 2010; Nestel et al., 2012; Van Eldik et al., 2016). A maladaptive diet and lifestyle are the dominant underlying causes of systemic inflammation (de Koning and Rabelink, 2002; O'Keefe et al., 2008). Processed and energy-rich foods and drinks can lead to exaggerated postprandial elevations in plasma glucose and triglycerides. Due to our increased intake of these foods in Western societies, postprandial hyperlipemia and hyperglycemia are common (O'Keefe and Bell, 2007), and postprandial lipemia in itself is an independent risk factor for CVD, obesity, metabolic syndrome, and type 2 diabetes (Lecomte et al., 2015). These spikes in triglycerides and glucose can generate an excess of plasma reactive oxygen species that can initiate pro-inflammatory reactions (de Koning and Rabelink, 2002; Hyson et al., 2003; O'Keefe et al., 2008). Activated immune cells can promote or suppress inflammation; reducing inflammation is essential to avoid long-lasting damage to host tissue (Nathan, 2002). Mediators of inflammation are central to maintaining equilibrium in an acute inflammatory response. If an acute inflammatory response is not resolved, it will continue, and the subsequent inflammatory microen- 
vironment will disrupt tissue homeostasis, leading to a low-grade chronic inflammatory condition (Nasopoulou and Zabetakis, 2015).

Atherosclerosis is a chronic progressive vascular disease that develops through the formation of foam cells, atherosclerotic plaque, fissure, erosion, and rupture, leading to a major cardiovascular event. Endothelial dysfunction, regarded as the initial stage of atherosclerosis development (Mudau et al., 2012), is characterized by oxidative stress and gives rise to decrease in the bioavailability of vasodilators such as nitric oxide (Bonetti et al., 2003). This in turn causes increased endothelial permeability and expression of pro-inflammatory cells (e.g., monocytes; Tselepis and Chapman, 2002). Due to the phenotypic polarization of monocytes and the activation of other immune cells, the expression of pro-inflammatory and pro-thrombotic factors is increased, including reactive oxygen species, metalloproteases, phospholipases, cytokines, bioactive lipids such as platelet-activating factor (PAF), and tissue factors such as tumor necrosis factor- $\alpha$ (TNF- $\alpha$; Libby, 1995; Tselepis and Chapman, 2002). Chronic exposure to CVD risk factors such as hyperlipemia, hyperglycemia, smoking, obesity, hypertension, or dietary factors initializes the onset of endothelial dysfunction (Deanfield et al., 2007).

High levels of serum lipids, particularly low-density lipoprotein cholesterol, have long been associated with the development of atherosclerosis (Choy et al., 2004). Products of lipid oxidation, such as oxidized phospholipids, are recognized as chronic inducers of inflammation, characteristic of atherosclerosis (Bochkov, 2007). However, some oxidized phospholipids may possess protective effects against inflammation (Mauerhofer et al., 2016). Dietary intake of lipids plays a key role in suppressing inflammatory processes. Dairy products were once thought to be detrimental to health by inducing inflammatory diseases such as CVD, but recent evidence suggests that they are associated with a beneficial or neutral effect on inflammation (Labonté et al., 2013). Nevertheless, the mechanisms underlying the observed beneficial effects of specific dairy product consumption and inflammation remain unclear (Da Silva and Rudkowska, 2015).

Platelet-activating factor is a crucial potent inflammatory and thrombotic phospholipid mediator of atherosclerosis (Demopoulos et al., 1979, 2003). It is the most potent lipid mediator of inflammation (Prescott et al., 2000) and is essential for the activation of leukocytes and their binding to endothelial cells (Liapikos et al., 1994). Lipid microconstituents of specific foods exert in vitro anti-inflammatory and antithrombotic activities by inhibiting PAF (Zabetakis, 2013). However, research into the effects of dairy products on inflammatory mediators such as PAF has been limited (Huth and Park, 2012).

Inflammation is firmly linked with inflammatory bowel diseases (Lasry et al., 2016) and the development of colorectal cancer - the third most commonly diagnosed cancer in the Western world (García-Barros et al., 2014). Dairy product consumption has been associated with protective effects against colorectal cancer and other inflammatory diseases (Panagiotakos et al., 2010; Aune et al., 2012; Crichton and Alkerwi, 2014; Rashidi Pour Fard et al., 2015), although this is sometimes controversial. These beneficial effects have been attributed to specific short-chain and medium-chain SFA, dairy trans-fatty acids, and milk proteins, which may have a synergistic effect with other micronutrients such as calcium, magnesium, and potassium (Da Silva and Rudkowska, 2015).

\section{ANTI-INFLAMMATORY PROPERTIES OF LIPIDS IN DAIRY PRODUCTS}

\section{In Vitro}

In vitro studies of dairy-derived fatty acids generally focus on the effects of $\alpha$-linolenic acid, docosahexaenoic acid, eicosapentaenoic acid, linoleic acid, and their derivatives. For this review, we have chosen to highlight the putative anti-inflammatory properties of dairy-derived polar lipids. The polar lipid fractions of food consist of phospholipids and sphingolipids, located in the milk fat globule membrane of dairy products. This is a complex biological membrane surrounding the fat globules in milk, primarily consisting of membranespecific proteins and polar lipids (Phan et al., 2016). The majority of studies investigating the effects of polar lipids on inflammation have been performed using soy-extracted polar lipids (Castro-Gómez et al., 2015). Research by Antonopoulou et al. (1996) on cow's milk and yogurt has shown that both products contain lipids capable of inhibiting PAF-induced platelet aggregation.

The anti-inflammatory activities of lipids in goat and sheep products have been studied in traditional Greek Ladotyri and Kefalotyri sheep cheeses (Tsorotioti et al., 2014), and the lipid fractions of both cheeses exhibited inhibitory activity toward PAF-induced platelet aggregation. Further analysis of the lipid fractions in both cheeses, by thin layer chromatography, has shown that the most biologically active lipid fractions contained sphingomyelin, phosphatidylcholine, and phosphatidylethanolamine lipid derivatives. However, these lipid fractions do not always present as a typical phospholipid structure; they share a similar structure to phosphatidylcholine derivatives as reported by Nasopoulou et al. (2014). Researchers have demonstrated 
that phosphatidylcholine has several anti-inflammatory effects (Treede et al., 2007; Erös et al., 2009).

Poutzalis et al. (2016) compared the PAF-inhibiting properties of goat products (milk, yogurt, and cheese), and all goat samples possessed PAF inhibitors. The resulting data indicated an increasing trend of PAF inhibition during lipolysis (i.e., incubation of milk to yogurt and cheese). This trend has been attributed to fermentation involving microorganisms such as Lactobacillus delbrueckii ssp. bulgaricus and Streptococcus thermophilus. The animal origin of milk plays an important role, as suggested by Megalemou et al. (2017); the most potent PAF inhibitors were found in yogurts produced from ovine and caprine milk, as opposed to yogurts from bovine milk.

\section{In Vivo}

Dillehay et al. (1994) has shown that diets containing varying amounts of milk-derived sphingomyelin reduced the number of aberrant crypt foci (pre-neoplastic lesions) in the colon of carcinogen-treated mice. Synthetic sphingomyelin also exhibited suppression of aberrant crypt foci, comparable with the sphingomyelin compounds of milk origin, indicating that possible co-purified contaminants were not responsible for the resulting anti-inflammatory activity (Schmelz et al., 1997). Further studies have used sphingomyelin isolated from powdered low-fat milk, buttermilk, and glycerophospholipids (Schmelz et al., 1996; Schmelz et al., 2000). Further in vivo experiments by Mazzei et al. (2011) examined the suppression of dextran sodium sulfate-induced colitis and azoxymethane-induced colon cancer by dietary sphingomyelin from a bovine milk source in mice that lacked or possessed functional peroxisome-activated receptor $\gamma(\mathbf{P P A R}-\gamma)$ in intestinal, epithelial, and immune cells. The sphingomyelin diet reduced inflammation and the development of colon cancer. These findings were linked to improved preservation of the colonic microscopic structure and an increased survival rate in the mice. Several genes associated with promoting cancer and genes that exerted anti-tumor functions were down- or upregulated, respectively, by dietary sphingomyelin in PPAR- $\gamma$ expressing mice. This finding suggests that PPAR- $\gamma$ may play a protective role in the prevention of colon cancer with dietary sphingomyelin. This group has also shown that sphingomyelin may be beneficial in preventing the progression of breast cancer (Simon et al., 2010) and ovarian cancer (Babahosseini et al., 2012).

Obesity is also strongly associated with increased risk of CVD and cancer. A study by Lecomte et al. (2016) found that a high-fat diet incorporating milk polar lipids fed to mice did not induce white adipose tissue hypertrophy and mRNA markers of inflammation, in contrast to mice fed high-fat diets incorporating soybean polar lipids (lecithin). The study observed that soybean polar lipids led to features of obesity-induced adipose tissue dysfunction (hyperplasia and hypertrophy) combined with infiltration by inflammatory cells, increased expression of TNF- $\alpha$, mono-chemoattractant protein-1, LPS-binding protein, and leptin. Although the dietary lipid intake was similar, these inflammatory markers were not increased with milk polar lipid consumption. Instead, milk polar lipids exhibited protective anti-inflammatory activity with lower gene expression of a marker of macrophage infiltration (CD68) in white adipose tissue and lower plasma concentrations of LPS-binding protein, a transporter of endotoxins. The study also deduced that mice that consumed milk polar lipids might have had a stronger colon barrier due to an increase in mucus-producing goblet cells in the colon. Impairment of the intestinal barrier can contribute to the passage of endotoxins into the circulatory system, leading to the activation of several inflammatory pathways (Cani et al., 2012). Lecomte et al. (2016) hypothesized that the stronger intestinal barrier induced prevented high-fat-induced macrophage infiltration in the white adipose tissue, preventing the onset of chronic inflammation. A similar increase in goblet cells was observed in another study in mice fed a high-fat diet supplemented with pasture-derived dairy cream versus mice fed a high-fat diet and standard dairy cream (Benoit et al., 2014).

Various groups (Lecomte et al., 2016; Nilsson, 2016; Norris et al., 2016) have attributed the anti-inflammatory effects of milk polar lipids to the presence of the sphingomyelin-derived lipids. Dietary sphingomyelin has exhibited the ability to repress inflammation-driven colorectal cancer (Mazzei et al., 2011) by modulating the inflammatory response (El Alwani et al., 2006). Sphingolipid metabolites such as sphingosine-1-phosphate, ceramide-1-phosphate, and ceramide are crucial biologically active signaling molecules involved in the regulation of key physiological functions and implicated in a multitude of pathological processes and inflammation-associated diseases (Hannun and Obeid, 2008; Gomez-Muñoz et al., 2016). However, current views are that these metabolites may contribute not only to antiinflammatory responses, but also to pro-inflammatory ones.

Gomez-Muñoz et al. (2016) indicated in their review that ceramides are of a particular concern, because they can cause inflammatory responses from several cells. The role of sphingosine-1-phosphate in inflammation is controversial, whereas depending on the cell type, ceramide-1-phosphate can have either anti or pro-inflammatory activity. Further dietary intervention 
studies are required to illustrate the effect of individual sphingolipids in modulating inflammation in human responses.

\section{Ex Vivo}

Relatively few published ex vivo studies have examined the effects of conventional dairy product consumption on inflammatory markers in healthy or diseased humans. Table 1 presents several selected clinical trials from 2009 to 2016 that measured the effects of dairy consumption on inflammation markers. With the exception of Labonté et al. (2014), the trials assessed the effects only in obese or overweight participants. The resulting outcomes of these trials are conflicting and indicate no clear consensus on how dairy consumption affects inflammatory markers in obese or healthy populations. It must be noted that many of the studies assessed the pro- and anti-inflammatory capacities of lowfat milk and dairy products. Global trends show that full-fat dairy consumption has fallen since the 1970s, and low-fat dairy consumption has increased (Feeney et al., 2016). The ex vivo studies presented here neglected the fact that the fat components of bovine, ovine, and caprine milk have significant nutritional value and possess bioactive lipids with anti-inflammatory properties (Contarini and Povolo, 2013; Tsorotioti et al., 2014; Poutzalis et al., 2016).

Conjugated linoleic acid is a collective term for several isomers of linoleic acid (Bhattacharya et al., 2006) that possess putative modulating effects on pro- and antiinflammatory responses (Reynolds and Roche, 2010). The richest natural dietary sources of CLA for human consumption are milk, dairy products, meat, and meat products (Benjamin and Spener, 2009). Rumenic acid, the cis-9,trans-11 isomer, is the predominant form of CLA, representing over $90 \%$ of total CLA in ruminant milk fat (Savoini et al., 2010). Trans-10,cis-12 CLA is another common isomer that is the focus of many studies, and it accounts for 1 to $10 \%$ of total CLA (Reynolds and Roche, 2010). Consumption of trans-10,cis-12 CLA is associated with anti-adipogenic effects in in vivo and in vitro models (Park et al., 1999; Kang et al., 2003; Yeganeh et al., 2016); however, clinical trials have been inconsistent in their results (Tricon et al., 2006; Whigham et al., 2007; Plourde et al., 2008). The total fat and CLA content in ruminant milk varies between species and depends on several biological and environmental factors (Lock and Bauman, 2004; Bainbridge et al., 2016). Conjugated linoleic acid is an intermediate product of the microbial biohydrogenation of linoleic acid to stearic acid in the rumen of animals Buccioni et al. (2012) and is produced endogenously in mam- mary tissue from trans vaccenic acid (Yaqoob, 2015). The diet of a dairy animal is the main factor affecting the CLA content of its milk (Siurana and Calsamiglia, 2016). Despite inconsistent data from CLA supplement studies, researchers have started to develop processes to naturally increase the cis-9,trans-11 CLA content of milk and dairy products (Yaqoob, 2015). This has led to a surge in the enrichment of milk and dairy products with CLA by researchers and commercial entities who aim to produce novel functional foods.

In animal models, CLA has been reported to possess anti-atherogenic, anti-carcinogenic, and anti-inflammatory properties; it may also reduce adipose tissue mass and protect against the final stages of systemic lupus erythematosus (Kritchevsky et al., 2000; Reynolds and Roche, 2010; Bruen et al., 2017). However, studies are inconsistent concerning the effects of CLA consumption in humans (Plourde et al., 2008). Scientists have postulated that the health effects of CLA may be isomer-dependent and divergent in their effects (Roche et al., 2002; Arbonés-Mainar et al., 2006; Yeganeh et al., 2016). The majority of studies investigating the anti-inflammatory potential of CLA consumption have focused on cis-9,trans-11 CLA. Table 2 highlights some of the studies that have focused on human consumption of dairy products enriched in CLA and their effect on the concentration of inflammatory markers and hemorheological values.

Sofi et al. (2010) concluded that the consumption of cis-9,trans-11 CLA in ewe cheese had a beneficial effect on risk factors associated with CVD. Although they observed no significant changes in the lipid profile of the participants during the intervention phase, they did see a significant reduction of inflammatory cytokines and platelet aggregation induced by arachidonic acid. Although the results were from a limited study group, this promising evidence suggests that the consumption of cis-9,trans-11 CLA from pecorino cheese may reduce the inflammatory response and prevent subsequent atherosclerosis and related inflammatory diseases.

The majority of the studies presented in Table 2 used CLA concentrations of less than $3 \mathrm{~g} / \mathrm{d}$. Studies show that high amounts of CLA (approximately 3 to $3.2 \mathrm{~g} / \mathrm{d}$ ) are required to yield plasma concentrations of CLA and metabolites sufficient to exert nutritional effects in experimental animal models (Mele et al., 2013; Rodríguez-Alcalá et al., 2013). However, Raff et al. (2008) have hypothesized that the necessary level may be over 10 times higher in reality. It is plausible that the concentrations of CLA used in the studies in Table 2 were not high enough to exert beneficial effects, although this was not the case for the Sofi et al. (2010) study, in which participants consumed approximately 
INVITED REVIEW: ANTI-INFLAMMATORY PROPERTIES OF DAIRY LIPIDS

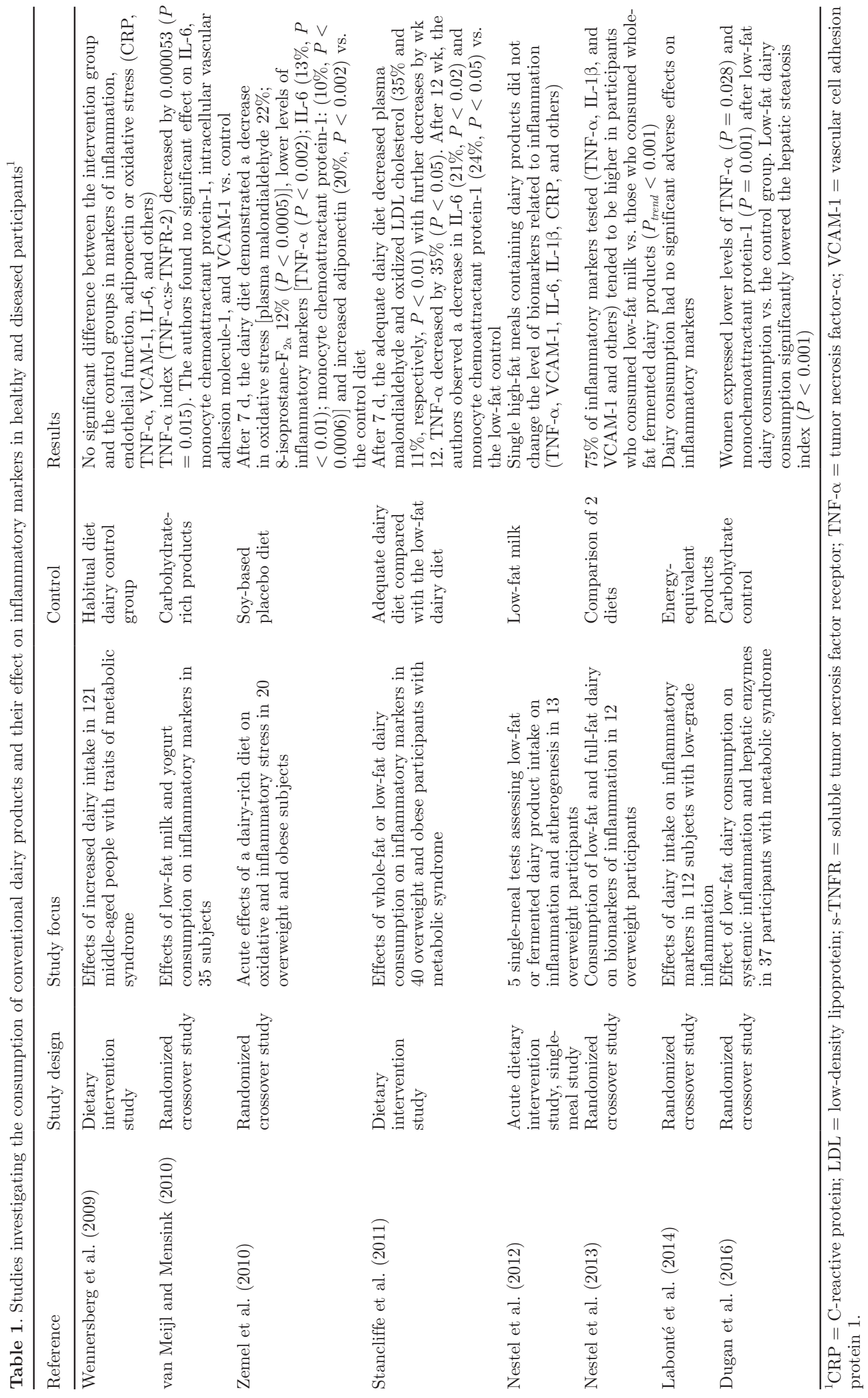




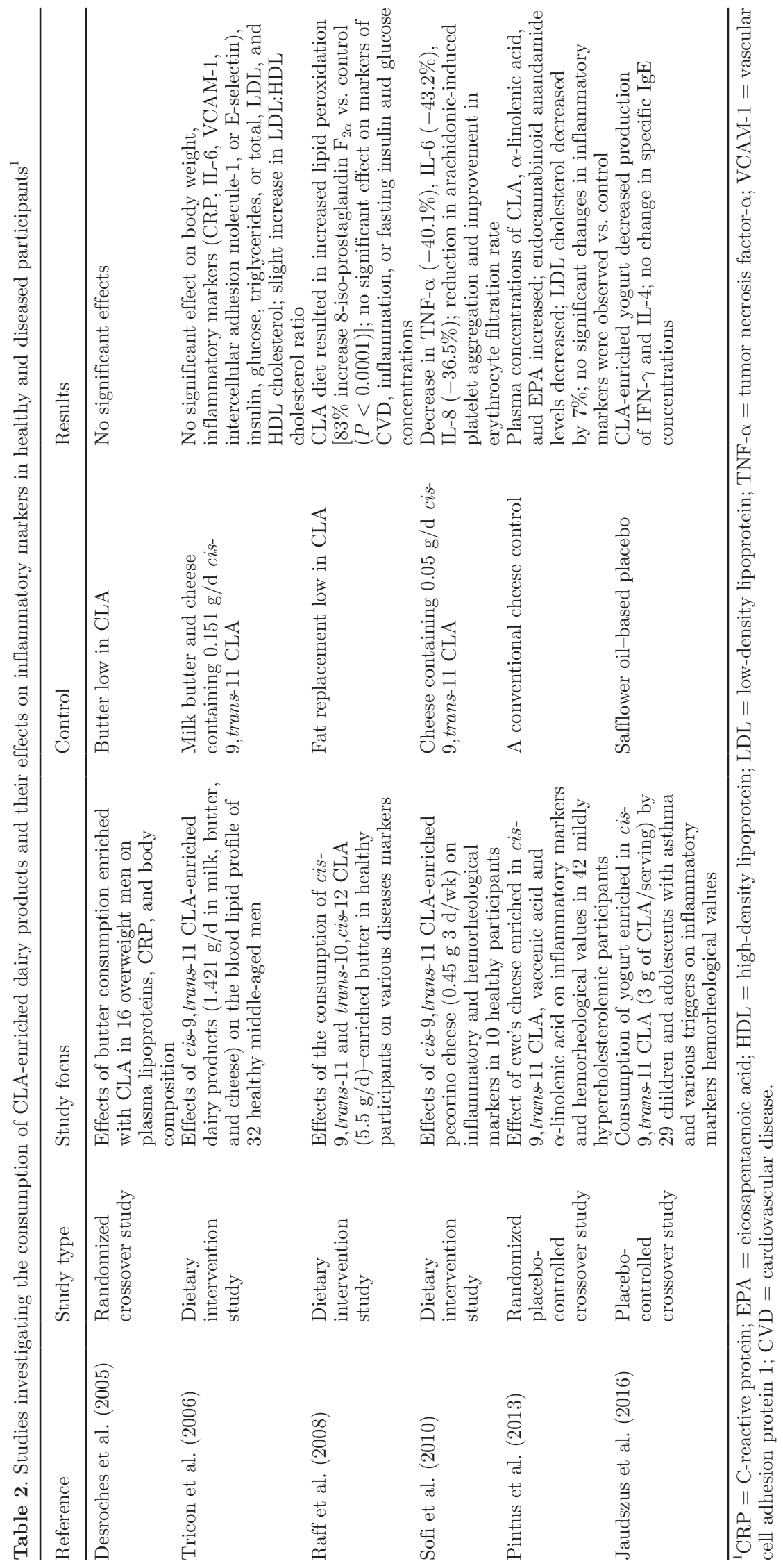


$0.45 \mathrm{~g} / \mathrm{d}$. More clinical studies are required to confirm whether the consumption of CLA has a beneficial effect for chronic systemic inflammation.

The n-6/n-3 PUFA ratio has also dominated research in recent years. We have evolved to consume $n-6 / n-3$ PUFA in a 1:1 ratio. This ratio has increased dramatically, with estimates suggesting a ratio closer to $15: 1$ or 17:1 (Simopoulos, 2002a). The marked increase in $n-6$ PUFA consumption is due to our evolution of mechanized food production over the last 100 years, characterized by increased meat and cereal consumption rich in arachidonic acid and n-6 PUFA, and leading to a decrease in consumption of n- 3 fatty acids (Simopoulos, 2002a). This ratio imbalance has been associated with the pathogenesis of several inflammatory diseases (Simopoulos, 2002b; Simopoulos, 2004). Recent research by Simopoulos (2016) has found that this ratio imbalance may also coincide with a greater risk of obesity, which further exacerbates chronic inflammatory diseases and leads to poorer health. Numerous studies and reviews have highlighted the potential benefits of n-3 long-chain PUFA (LC-PUFA) supplementation from marine sources to prevent chronic inflammatory diseases (Calder, 2002; Wall et al., 2010). Conventional dairy products are naturally low in n-3 LC-PUFA (Dawczynski et al., 2009), and this has led to an interest in meeting our dietary requirements by altering the diets of dairy-producing animals, enriching dairy products directly. Many studies have enhanced the lipid composition of dairy products by adding bioactive compounds, oils, and fats from plant and marine sources in the production of yogurt (Espírito Santo et al., 2010; Georgakouli et al., 2016; Robertson et al., 2016). Table 3 presents studies that focus on the effects of dairy products enriched with PUFA on inflammatory markers in humans.

Dawczynski et al. (2009) investigated the effects of n-3 LC-PUFA-enriched dairy product consumption on inflammatory markers in patients with rheumatoid arthritis. Consumption of these supplemented dairy products improved several immunological and hemorheological markers, possibly benefiting rheumatoid arthritis patients, because they have increased risks of CVD due to prolonged elevation of C-reactive protein and poor vascular function (Peters et al., 2010). The same authors also studied how the consumption of n-3 LCPUFA-supplemented dairy products affected mildly hypertriacylglycerolemic patients in relation to CVD (Dawczynski et al., 2010). These products resulted in more favorable blood lipid parameters, no evidence of oxidative DNA damage, and a higher n-3 fatty acid index.

Dawczynski et al. (2013) further assessed these PUFA-enriched products by conducting a randomized, placebo-controlled intervention study using n-3 LCPUFA-supplemented yogurts. Consumption of these enriched dairy products resulted in a dose-dependent improvement of cardiovascular risk factors such as the n-3 fatty acid index, high-density lipoprotein cholesterol levels, triacylglycerols, low-/high-density lipoprotein cholesterol ratios, and arachidonic acid/eicosapentaenoic acid ratios in blood plasma and red blood cells of hypertriacylglycerolemic participants (Tholstrup et al., 2006).

These ex vivo studies focused mainly on non-healthy participants and have highlighted inconsistencies in confirming the links between dairy fat intake and inflammatory markers. Many of these discrepancies are due to the type of study design employed, the sources of milk used, and the processes used to create the dairy products. A study investigating the effect of dairy consumption on biomarkers of inflammation in healthy participants by Labonté et al. (2014) observed that short-term consumption of a combination of low-fat milk, low-fat yogurt, and regular-fat cheese had no effect on circulating inflammatory markers. As previously stated, researchers who limited their investigations to low-fat dairy consumption essentially disregarded the influence of the lipid fraction on inflammatory markers and did not obtain an accurate indication of their potential health effects.

Chronic inflammation persists in those who are obese due to the increased mass of adipose tissue and resulting increase in adipokines. This significantly contributes to endothelial dysfunction and CVD development (Guarner and Rubio-Ruiz, 2014). The elderly are also vulnerable to chronic inflammatory diseases such as metabolic syndrome and CVD because of elevated inflammatory markers and insulin levels due to immunosenescence, obesity, and sarcopenia (Guarner and Rubio-Ruiz, 2014). Rashidi Pour Fard et al. (2015) reported that total dairy consumption was not associated with lower C-reactive protein or increased risk of insulin resistance in a study of 107 elderly participants. A large cohort study by Wennersberg et al. (2009), reported no decrease in the level of inflammatory biomarkers in obese participants with metabolic syndrome who raised their consumption of dairy foods from habitual levels of consumption.

Although these studies are reassuring that dairy consumption is not associated with an increase in systemic inflammation, more research is required to discern whether the dairy products - and in particular the lipid fractions - have anti-inflammatory properties. The ex vivo studies presented here show that more research is required to decipher: (a) what exact dairy products and their lipid components are involved in the modulation of inflammatory biomarkers; (b) what concentrations 
LORDAN AND ZABETAKIS

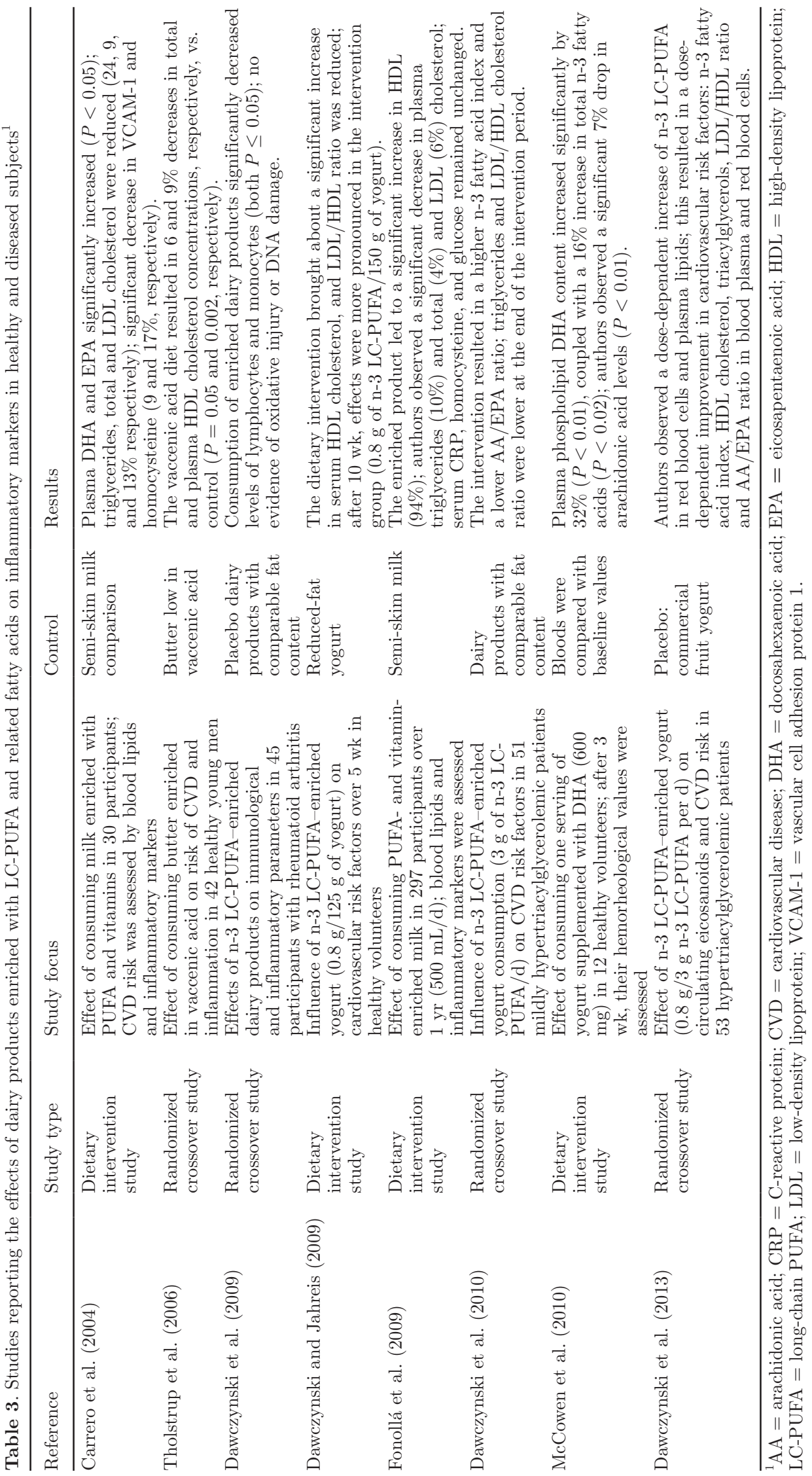


of these lipids are required to have a beneficial effect, and are they bioavailable; (c) whether the source of these bioactive lipids matters (bovine, ovine, caprine, or fortified/enriched products); and (d) what potential health implications are associated with the consumption of these dairy lipids.

\section{Epidemiological}

Epidemiological studies generally report overall dairy consumption and are not designed to give specific information about certain micronutrients or specific products. These studies commonly disregard the measurement of inflammatory markers over long periods because of the costs and logistical problems related to assessing large cohorts. Table 4 highlights several cohort studies that have scrutinized the consumption of dairy products relative to the risk of chronic inflammatory diseases, with an emphasis on CVD. Elwood et al. (2004b) identified 10 studies that estimated the intake of milk or calcium from dairy sources in relation to incidence of ischemic heart disease and ischemic stroke, and the cohort of studies provided no convincing evidence that milk consumption was harmful. In fact, the most recent studies in both Table 4 and 5 as a whole suggest that milk intake may be associated with a modest reduction in heart disease and stroke risk. Meta-analyses of dairy consumption also generally report that dairy is inversely associated with inflammatory diseases such as CVD (Alexander et al., 2016), metabolic syndrome (Chen et al., 2015), type 2 diabetes (Chen et al., 2014), and cancer (Li et al., 2011; Larsson et al., 2015). The evidence is mounting to re-evaluate our stance on the consumption of dairy products with respect to inflammatory diseases. It is also important that epidemiological study designs include the evaluation of inflammatory markers to decipher what foods might exacerbate inflammatory conditions.

The ATTICA study (Panagiotakos et al., 2010) investigated how the consumption of dairy products affects levels of inflammatory markers in blood samples from fasting adults who had no evidence of previous chronic inflammatory disease. After adjusting for potential confounders, levels of inflammatory markers such as C-reactive protein, IL-6, and TNF- $\alpha$ were 29, 9 , and $20 \%$ lower, respectively $(P=0.01)$, in people who consumed more than 14 servings of dairy per week compared with those who had fewer than 8 servings per week $(P=0.05)$. This inverse association between dairy consumption and levels of inflammatory markers in healthy adults indicates that dairy products may be protective against chronic inflammatory diseases.

Cohort studies have several limitations, because they are usually conducted in homogeneous populations who share a similar diet, lifestyle, and are from the same geographical region. Therefore, they may not apply to populations from other geographical regions. Wang et al. (2015) conducted such a study and elucidated an inverse association between low consumption of dairy products ( 1 to 2 times a month) in men and all-cause mortality. However, they found lower all-cause mortality only found in women who drank dairy products 3 to 4 times a week. These levels of dairy consumption were very low and not comparable to Western societies. Milk and dairy intake in Japan has been much lower than in Europe and Western countries, with liquid milk accounting for $92.1 \%$ of the total Japanese dairy intake in the 1990s (Wang et al., 2015). Similar studies have demonstrated the benefits of dairy product consumption in Japanese cohorts, including lower insulin resistance due to full-fat dairy product intake (Akter et al., 2013) and lower CVD risk in women who consumed mainly low-fat milk (Kondo et al., 2013). These studies may be useful for defining dietary recommendations in Asian societies, but not in Western societies. Many of the studies presented in Tables 4 and 5 are from Western countries, which represent some of the most recognized studies examining the effects of dairy product consumption. The participants recruited in these studies consumed dairy products on a regular basis, and their diets included yogurt and cheese, not just liquid milk. Although yogurt and cheese are derived from milk, they have similar and varied effects on health compared to milk intake. The participants of the studies in Tables 4 and 5 also consumed dairy products more regularly than in the study by Wang et al. (2015). Thus, the study by Wang et al. (2015) is not applicable to other countries where people consume dairy products on a regular basis.

In epidemiological studies, researchers often examined the health effects of low-fat dairy products over full-fat products, despite the limitations of such an approach as discussed above. Louie et al. (2013) found no consistent association between dairy intake and the risk of coronary heart disease, stroke, or CVD mortality in a population that ingested low-fat dairy products. There is currently no consensus on whether low-fat dairy products are associated with a lower risk of CVD (Benatar et al., 2013). Although low-fat dairy products are themselves nutrient-dense and have lowering effects on blood pressure (Appel et al., 1997; van Meijl and Mensink, 2011), more research is required to deduce whether these findings are similar for full-fat dairy products. As epidemiological research progresses, analyzing low-fat and full-fat dairy products separately compared with a control may allow for accurate indication of the effects of dairy products on human health. This will also allow researchers to design more in-depth studies to decipher 


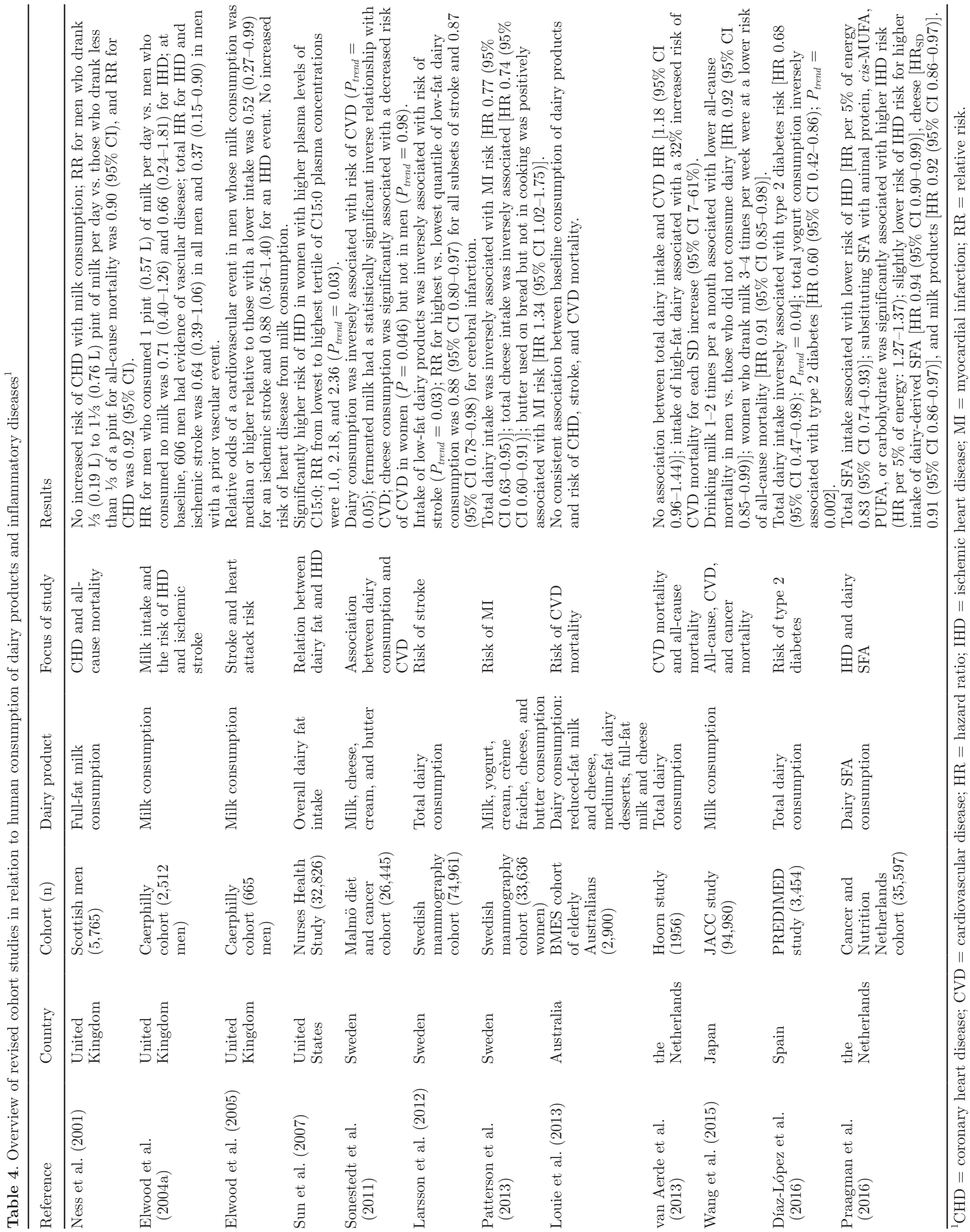




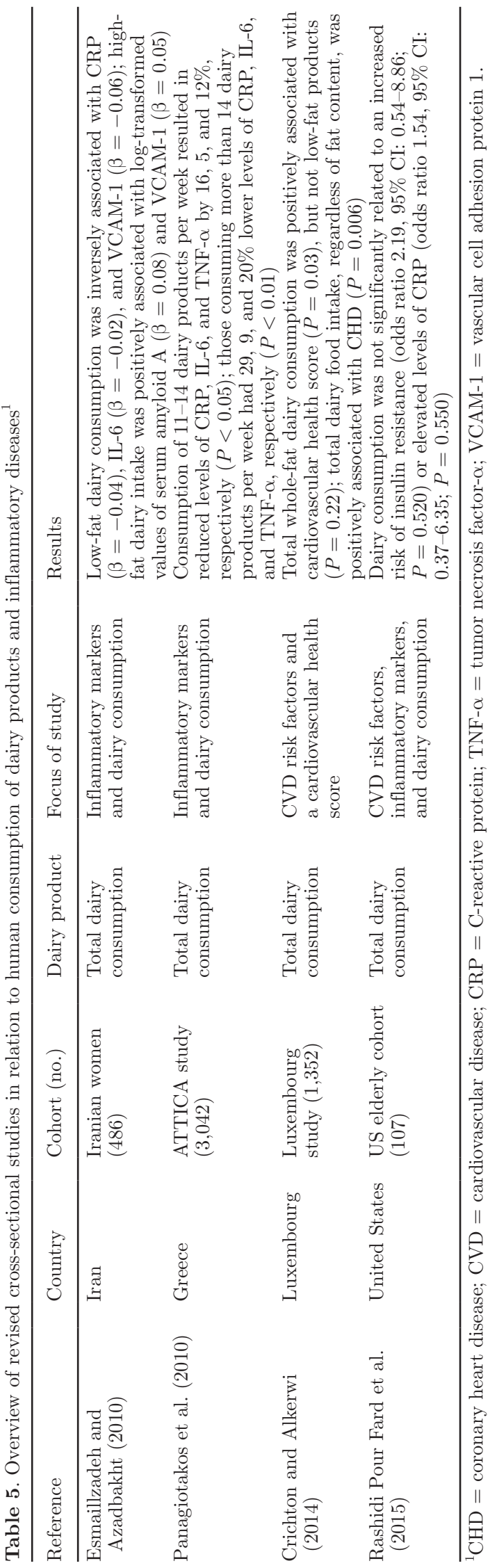

the pro- or anti-inflammatory mechanisms of lipids and other macronutrients. A credible approach could be the use of metabolomics to assess different dietary patterns and biomarkers (O'Sullivan et al., 2011). Advantages to these methodologies include reducing human error and subjective bias due to errors in reporting dietary intake and the misclassification of foods (Favé et al., 2009). However, specific and definitive markers for dairy consumption still need to be identified, and models capable of quantifying dairy intake based on the analysis of biological samples are still warranted (Zheng et al., 2015).

\section{FUTURE RESEARCH AVENUES AND CONCLUSIONS}

In this review, we have discussed the anti-inflammatory properties of dairy-derived bioactive lipids. We have examined certain limitations (i.e., how the antiinflammatory activity of certain lipid fractions in dairy products have yet to be fully characterized, largely due to the negative perception of fat in dairy products) and have proposed that the polar lipid fractions of dairy products are overlooked, probably because they constitute $<1 \%$ of the total lipid content of most dairy products, despite their strong anti-inflammatory activities (Megson et al., 2016). Globally, ongoing research is focused on the structural elucidation of cardioprotective lipids. Current trends are toward the production of products with enhanced activities against CVD, cancer, and obesity.

\section{ACKNOWLEDGMENTS}

The authors acknowledge the financial support of both Enterprise Ireland (feasibility study grant reference: IP-2016-0488Y) and the Department of Biological Sciences, University of Limerick, Ireland.

\section{REFERENCES}

Akter, S., K. Kurotani, A. Nanri, N. M. Pham, M. Sato, H. Hayabuchi, and T. Mizoue. 2013. Dairy consumption is associated with decreased insulin resistance among the Japanese. Nutr. Res. 33:286292. https://doi.org/10.1016/j.nutres.2013.01.009.

Alexander, D. D., L. C. Bylsma, A. J. Vargas, S. S. Cohen, A. Doucette, M. Mohamed, S. R. Irvin, P. E. Miller, H. Watson, and J. P. Fryzek. 2016. Dairy consumption and CVD: A systematic review and meta-analysis. Br. J. Nutr. 115:737-750. https://doi. org/10.1017/S0007114515005000.

Antonopoulou, S., C. E. Semidalas, S. Koussissis, and C. A. Demopoulos. 1996. Platelet-activating factor (PAF) antagonists in foods: A study of lipids with PAF or anti-PAF-like activity in cow's milk and yogurt. J. Agric. Food Chem. 44:3047-3051.

Appel, L. J., T. J. Moore, E. Obarzanek, W. M. Vollmer, L. P. Svetkey, F. M. Sacks, G. A. Bray, T. M. Vogt, J. A. Cutler, M. M. Windhauser, P. H. Lin, and N. Karanja. 1997. A clinical trial of the effects of dietary patterns on blood pressure. DASH Collaborative Research Group. N. Engl. J. Med. 336:1117-1124. https://doi. org/10.1056/NEJM199704173361601. 
Arbonés-Mainar, J. M., M. A. Navarro, M. A. Guzmán, C. Arnal, J. C. Surra, S. Acín, R. Carnicer, J. Osada, and H. M. Roche. 2006. Selective effect of conjugated linoleic acid isomers on atherosclerotic lesion development in apolipoprotein $\mathrm{E}$ knockout mice. Atherosclerosis 189:318-327. https://doi.org/10.1016/j. atherosclerosis.2006.01.015.

Aune, D., R. Lau, D. Chan, R. Vieira, D. Greenwood, E. Kampman, and T. Norat. 2012. Dairy products and colorectal cancer risk: A systematic review and meta-analysis of cohort studies. Ann. Oncol. 23:37-45. https://doi.org/10.1093/annonc/mdr269.

Babahosseini, H., P. C. Roberts, E. M. Schmelz, and M. Agah. 2012 Roles of bioactive sphingolipid metabolites in ovarian cancer cell biomechanics. Pages 2436-2439 in Proc. 2012 Annu. Int. Conf. IEEE Engineering in Medicine and Biology Society, San Diego, CA. http://ieeexplore.ieee.org/abstract/document/6346456/.

Bainbridge, M. L., L. M. Cersosimo, A.-D. G. Wright, and J. Kraft. 2016. Content and composition of branched-chain fatty acids in bovine milk are affected by lactation stage and breed of dairy cow. PLoS One 11:e0150386 https://doi.org/10.1371/journal. pone.0150386.

Benatar, J. R., K. Sidhu, and R. A. Stewart. 2013. Effects of high and low fat dairy food on cardio-metabolic risk factors: A metaanalysis of randomized studies. PLoS One 8:e76480 https://doi. org/10.1371/journal.pone.0076480.

Benjamin, S., and F. Spener. 2009. Conjugated linoleic acids as functional food: An insight into their health benefits. Nutr. Metab. (Lond) 6:36. https://doi.org/10.1186/1743-7075-6-36.

Benoit, B., P. Plaisancié, A. Géloën, M. Estienne, C. Debard, E. Meugnier, E. Loizon, P. Daira, J. Bodennec, O. Cousin, H. Vidal, F. Laugerette, and M.-C. Michalski. 2014. Pasture v. standard dairy cream in high-fat diet-fed mice: Improved metabolic outcomes and stronger intestinal barrier. Br. J. Nutr. 112:520-535. https://doi. org/10.1017/S0007114514001172.

Bhattacharya, A., J. Banu, M. Rahman, J. Causey, and G. Fernandes, 2006. Biological effects of conjugated linoleic acids in health and disease. J. Nutr. Biochem. 17:789-810. https://doi.org/10.1016/j. jnutbi0.2006.02.009.

Bochkov, V. N. 2007. Inflammatory profile of oxidized phospholipids. Thromb. Haemost. 97:348-354 https://doi.org/10.1160/TH06-080474.

Bonetti, P. O., L. O. Lerman, and A. Lerman. 2003. Endothelial dysfunction: A marker of atherosclerotic risk. Arterioscler. Thromb. Vasc. Biol. 23:168-175. https://doi.org/10.1161/01. atv.0000051384.43104.fc.

Bruen, R., S. Fitzsimons, and O. Belton. 2017. Atheroprotective effects of conjugated linoleic acid. Br. J. Clin. Pharmacol. 83:46-53. https://doi.org/10.1111/bcp.12948.

Buccioni, A., M. Decandia, S. Minieri, G. Molle, and A. Cabiddu. 2012. Lipid metabolism in the rumen: New insights on lipolysis and biohydrogenation with an emphasis on the role of endogenous plant factors. Anim. Feed Sci. Technol. 174:1-25. https://doi. org/10.1016/j.anifeedsci.2012.02.009.

Calder, P. C. 2002. Dietary modification of inflammation with lipids. Proc. Nutr. Soc. 61:345-358. https://doi.org/10.1079/ PNS2002166.

Calder, P. C., N. Ahluwalia, F. Brouns, T. Buetler, K. Clement, K. Cunningham, K. Esposito, L. S. Jönsson, H. Kolb, and M. Lansink. 2011. Dietary factors and low-grade inflammation in relation to overweight and obesity. Br. J. Nutr. 106(Suppl. 3):S5-S78. https://doi.org/10.1017/S0007114511005460.

Cani, P. D., M. Osto, L. Geurts, and A. Everard. 2012. Involvement of gut microbiota in the development of low-grade inflammation and type 2 diabetes associated with obesity. Gut Microbes 3:279-288. https://doi.org/10.4161/gmic.19625.

Carrero, J. J., L. Baró, J. Fonollá, M. González-Santiago, A. MartínezFérez, R. Castillo, J. Jiménez, J. J. Boza, and E. López-Huertas. 2004. Cardiovascular effects of milk enriched with $\omega-3$ polyunsaturated fatty acids, oleic acid, folic acid, and vitamins E and B6 in volunteers with mild hyperlipidemia. Nutrition 20:521-527. https://doi.org/10.1016/j.nut.2004.03.017.
Castro-Gómez, P., A. Garcia-Serrano, F. Visioli, and J. Fontecha 2015. Relevance of dietary glycerophospholipids and sphingolipids to human health. Prostaglandins Leukot. Essent. Fatty Acids 101:41-51. https://doi.org/10.1016/j.plefa.2015.07.004.

Chen, G. C., I. Szeto, L. Chen, S. Han, Y. Li, R. van Hekezen, and L. Qin. 2015. Dairy products consumption and metabolic syndrome in adults: Systematic review and meta-analysis of observational studies. Sci. Rep. 5:14606. https://doi.org/10.1038/srep14606.

Chen, M., Q. Sun, E. Giovannucci, D. Mozaffarian, J. E. Manson, W. C. Willett, and F. B. Hu. 2014. Dairy consumption and risk of type 2 diabetes: 3 cohorts of US adults and an updated meta-analysis. BMC Med. 12:215 https://doi.org/10.1186/s12916-014-0215-1.

Choy, P. C., Y. L. Siow, D. Mymin, and O. Karmin. 2004. Lipids and atherosclerosis. Biochem. Cell Biol. 82:212-224. https://doi. org/10.1139/o03-085.

Contarini, G., and M. Povolo. 2013. Phospholipids in milk fat: Composition, biological and technological significance, and analytical strategies. Int. J. Mol. Sci. 14:2808-2831. https://doi.org/10.3390/ ijms14022808.

Crichton, G. E., and A. Alkerwi. 2014. Dairy food intake is positively associated with cardiovascular health: Findings from Observation of Cardiovascular Risk Factors in Luxembourg study. Nutr. Res. 34:1036-1044. https://doi.org/10.1016/j.nutres.2014.04.002.

Da Silva, M. S., and I. Rudkowska. 2015. Dairy nutrients and their effect on inflammatory profile in molecular studies. Mol. Nutr. Food Res. 59:1249-1263. https://doi.org/10.1002/mnfr.201400569.

Dawczynski, C., and G. Jahreis. 2009. Prevention of cardiovascular diseases with milk products supplemented with long-chain omega3-fatty acids. Ernahr.-Umsch. 56:618-625.

Dawczynski, C., L. Martin, A. Wagner, and G. Jahreis. 2010. n-3 LCPUFA-enriched dairy products are able to reduce cardiovascular risk factors: A double-blind, cross-over study. Clin. Nutr. 29:592599. https://doi.org/10.1016/j.clnu.2010.02.008.

Dawczynski, C., K. A. Massey, C. Ness, M. Kiehntopf, S. Stepanow, M. Platzer, M. Grün, A. Nicolaou, and G. Jahreis. 2013. Randomized placebo-controlled intervention with n-3 LC-PUFA-supplemented yoghurt: Effects on circulating eicosanoids and cardiovascular risk factors. Clin. Nutr. 32:686-696. https://doi.org/10.1016/j. clnu.2012.12.010

Dawczynski, C., R. Schubert, G. Hein, A. Müller, T. Eidner, H. Vogelsang, S. Basu, and G. Jahreis. 2009. Long-term moderate intervention with n-3 long-chain PUFA-supplemented dairy products: Eaffects on pathophysiological biomarkers in patients with rheumatoid arthritis. Br. J. Nutr. 101:1517-1526. https://doi. org/10.1017/S0007114508076216.

de Koning, E. J. P., and T. J. Rabelink. 2002. Endothelial function in the post-prandial state. Atheroscler. Suppl. 3:11-16. https://doi. org/10.1016/S1567-5688(01)00008-3.

Deanfield, J. E., J. P. Halcox, and T. J. Rabelink. 2007 Endothelial function and dysfunction testing and clinical relevance. Circulation 115:1285-1295. https://doi.org/10.1161/ CIRCULATIONAHA.106.652859.

Demopoulos, C. A., R. N. Pinckard, and D. J. Hanahan. 1979. Platelet-activating factor. Evidence for 1-O-alkyl-2-acetyl-sn-glyceryl3 -phosphorylcholine as the active component (a new class of lipid chemical mediators). J. Biol. Chem. 254:9355-9358.

Demopoulos, C. A., H. C. Karantonis, and S. Antonopoulou. 2003. Platelet activating factor-A molecular link between atherosclerosis theories. Eur. J. Lipid Sci. Technol. 105:705-716. https://doi. org/10.1002/ejlt.200300845.

Desroches, S., P. Y. Chouinard, I. Galibois, L. Corneau, J. Delisle, B. Lamarche, P. Couture, and N. Bergeron. 2005. Lack of effect of dietary conjugated linoleic acids naturally incorporated into butter on the lipid profile and body composition of overweight and obese men. Am. J. Clin. Nutr. 82:309-319.

Díaz-López, A., M. Bulló, M. A. Martínez-González, D. Corella, R. Estruch, M. Fitó, E. Gómez-Gracia, M. Fiol, F. J. G. de la Corte, and E. Ros. 2016. Dairy product consumption and risk of type 2 diabetes in an elderly Spanish Mediterranean population at 
high cardiovascular risk. Eur. J. Nutr. 55:349-360. https://doi. org/10.1007/s00394-015-0855-8.

Dillehay, D. L., S. K. Webb, E. M. Schmelz, and A. H. Merrill Jr.. 1994. Dietary sphingomyelin inhibits 1,2-dimethylhydrazine-induced colon cancer in CF1 mice. J. Nutr. 124:615-620.

Dugan, C. E., D. Aguilar, Y. K. Park, J. Y. Lee, and M. L. Fernandez. 2016. Dairy consumption lowers systemic inflammation and liver enzymes in typically low-dairy consumers with clinical characteristics of metabolic syndrome. J. Am. Coll. Nutr. 35:255-261. https://doi.org/10.1080/07315724.2015.1022637.

El Alwani, M., B. X. Wu, L. M. Obeid, and Y. A. Hannun. 2006. Bioactive sphingolipids in the modulation of the inflammatory response. Pharmacol. Ther. 112:171-183. https://doi.org/10.1016/j. pharmthera.2006.04.004.

Elwood, P. C., J. E. Pickering, A. M. Fehily, J. Hughes, and A. R. Ness. 2004a. Milk drinking, ischaemic heart disease and ischaemic stroke I. Evidence from the Caerphilly cohort. Eur. J. Clin. Nutr. 58:711-717. https://doi.org/10.1038/sj.ejcn.1601868.

Elwood, P. C., J. E. Pickering, J. Hughes, A. M. Fehily, and A. R. Ness. 2004b. Milk drinking, ischaemic heart disease and ischaemic stroke II. Evidence from cohort studies. Eur. J. Clin. Nutr. 58:718724. https://doi.org/10.1038/sj.ejcn.1601869.

Elwood, P. C., J. Strain, P. J. Robson, A. M. Fehily, J. Hughes, J. Pickering, and A. Ness. 2005. Milk consumption, stroke, and heart attack risk: Evidence from the Caerphilly cohort of older men. J. Epidemiol. Community Health 59:502-505. https://doi. org/10.1136/jech.2004.027904.

Erős, G., S. Ibrahim, N. Siebert, M. Boros, and B. Vollmar. 2009. Oral phosphatidylcholine pretreatment alleviates the signs of experimental rheumatoid arthritis. Arthritis Res. Ther. 11:R43. https:// doi.org/10.1186/ar2651.

Esmaillzadeh, A., and L. Azadbakht. 2010. Dairy consumption and circulating levels of inflammatory markers among Iranian women. Public Health Nutr. 13:1395-1402. https://doi.org/10.1017/ S1368980009992126.

Espírito Santo, A. P. d., R. C. Silva, F. A. S. M. Soares, D. Anjos, L. A. Gioielli, and M. N. Oliveira. 2010. Açai pulp addition improves fatty acid profile and probiotic viability in yoghurt. Int. Dairy J. 20:415-422. https://doi.org/10.1016/j.idairyj.2010.01.002.

Favé, G., M. Beckmann, J. Draper, and J. C. Mathers. 2009. Measurement of dietary exposure: A challenging problem which may be overcome thanks to metabolomics? Genes Nutr. 4:135-141. https://doi.org/10.1007/s12263-009-0120-y.

Feeney, E. L., A. P. Nugent, B. Mc Nulty, J. Walton, A. Flynn, and E. R. Gibney. 2016. An overview of the contribution of dairy and cheese intakes to nutrient intakes in the Irish diet: Results from the National Adult Nutrition Survey. Br. J. Nutr. 115:709-717. https://doi.org/10.1017/S000711451500495X.

Fonollá, J., E. López-Huertas, F. J. Machado, D. Molina, I. Álvarez, E. Mármol, M. Navas, E. Palacín, M. J. García-Valls, B. Remón, J. J. Boza, and J. L. Marti. 2009. Milk enriched with "healthy fatty acids" improves cardiovascular risk markers and nutritional status in human volunteers. Nutrition 25:408-414. https://doi. $\operatorname{org} / 10.1016 /$ j.nut.2008.10.008.

García-Barros, M., N. Coant, J.-P. Truman, A. J. Snider, and Y. A. Hannun. 2014. Sphingolipids in colon cancer. Biochim. Biophys. Acta 1841:773-782. https://doi.org/10.1016/j.bbalip.2013.09.007.

Georgakouli, K., A. Mpesios, D. Kouretas, K. Petrotos, C. Mitsagga, I. Giavasis, and A. Z. Jamurtas. 2016. The effects of an olive fruit polyphenol-enriched yogurt on body composition, blood redox status, physiological and metabolic parameters and yogurt microflora. Nutrients 8:E344. https://doi.org/10.3390/nu8060344.

Gomez-Muñoz, A., N. Presa, A. Gomez-Larrauri, I.-G. Rivera, M. Trueba, and M. Ordoñez. 2016. Control of inflammatory responses by ceramide, sphingosine 1-phosphate and ceramide 1-phosphate. Prog. Lipid Res. 61:51-62. https://doi.org/10.1016/j. plipres.2015.09.002.

Greenberg, A. S., and M. S. Obin. 2006. Obesity and the role of adipose tissue in inflammation and metabolism. Am. J. Clin. Nutr. $83: 461 \mathrm{~S}-465 \mathrm{~S}$
Guarner, V., and M. E. Rubio-Ruiz. 2014. Low-grade systemic inflammation connects aging, metabolic syndrome and cardiovascular disease. Pages 99-106 in Aging and Health: A Systems Biology Perspective. Vol. 40. Karger Publishers, Basel, Switzerland.

Hannun, Y. A., and L. M. Obeid. 2008. Principles of bioactive lipid signalling: Lessons from sphingolipids. Nat. Rev. Mol. Cell Biol. 9:139-150. https://doi.org/10.1038/nrm2329.

Huth, P. J., and K. M. Park. 2012. Influence of dairy product and milk fat consumption on cardiovascular disease risk: A review of the evidence. Adv. Nutr. 3:266-285. https://doi.org/10.3945/ an.112.002030.

Hyson, D., J. C. Rutledge, and L. Berglund. 2003. Postprandial lipemia and cardiovascular disease. Curr. Atheroscler. Rep. 5:437-444. https://doi.org/10.1007/s11883-003-0033-y.

Jaudszus, A., J. G. Mainz, S. Pittag, S. Dornaus, C. Dopfer, A. Roth, and G. Jahreis. 2016. Effects of a dietary intervention with conjugated linoleic acid on immunological and metabolic parameters in children and adolescents with allergic asthma-A placebo-controlled pilot trial. Lipids Health Dis. 15:21 https://doi. org/10.1186/s12944-016-0187-6.

Kang, K., W. Liu, K. J. Albright, Y. Park, and M. W. Pariza. 2003. trans-10,cis-12 CLA inhibits differentiation of 3T3-L1 adipocytes and decreases PPAR $\gamma$ expression. Biochem. Biophys. Res. Commun. 303:795-799. https://doi.org/10.1016/S0006291X(03)00413-3.

Kondo, I., T. Ojima, M. Nakamura, S. Hayasaka, A. Hozawa, S. Saitoh, H. Ohnishi, H. Akasaka, T. Hayakawa, and Y. Murakami. 2013. Consumption of dairy products and death from cardiovascular disease in the Japanese general population: The NIPPON DATA80. J. Epidemiol. 23:47-54. https://doi.org/10.2188/jea.JE20120054.

Kratz, M., T. Baars, and S. Guyenet. 2013. The relationship between high-fat dairy consumption and obesity, cardiovascular, and metabolic disease. Eur. J. Nutr. 52:1-24. https://doi.org/10.1007/ s00394-012-0418-1.

Kritchevsky, D., S. A. Tepper, S. Wright, P. Tso, and S. K. Czarnecki. 2000. Influence of conjugated linoleic acid (CLA) on establishment and progression of atherosclerosis in rabbits. J. Am. Coll. Nutr. 19:472S-477S. https://doi.org/10.1080/07315724.2000.10718950.

Labonté, M.-È., P. Couture, C. Richard, S. Desroches, and B. Lamarche. 2013. Impact of dairy products on biomarkers of inflammation: A systematic review of randomized controlled nutritional intervention studies in overweight and obese adults. Am. J. Clin. Nutr. 97:706-717. https://doi.org/10.3945/ajcn.112.052217.

Labonté, M.-È., A. Cyr, M. M. Abdullah, M.-C. Lépine, M.-C. Vohl, P. Jones, P. Couture, and B. Lamarche. 2014. Dairy product consumption has no impact on biomarkers of inflammation among men and women with low-grade systemic inflammation. J. Nutr. 144:1760-1767. https://doi.org/10.3945/jn.114.200576.

Larsson, S. C., A. Crippa, N. Orsini, A. Wolk, and K. Michaëlsson. 2015. Milk consumption and mortality from all causes, cardiovascular disease, and cancer: A systematic review and meta-analysis. Nutrients 7:7749-7763. https://doi.org/10.3390/nu7095363.

Larsson, S. C., J. Virtamo, and A. Wolk. 2012. Dairy consumption and risk of stroke in Swedish women and men. Stroke 43:1775-1780. https://doi.org/10.1161/STROKEAHA.111.641944.

Lasry, A., A. Zinger, and Y. Ben-Neriah. 2016. Inflammatory networks underlying colorectal cancer. Nat. Immunol. 17:230-240. https:// doi.org/10.1038/ni.3384.

Lecomte, M., C. Bourlieu, E. Meugnier, A. Penhoat, D. Cheillan, G. Pineau, E. Loizon, M. Trauchessec, M. Claude, and O. Ménard. 2015. Milk polar lipids affect in vitro digestive lipolysis and postprandial lipid metabolism in mice. J. Nutr. 145:1770-1777. https://doi.org/10.3945/jn.115.212068.

Lecomte, M., L. Couëdelo, E. Meugnier, P. Plaisancié, M. Létisse, B. Benoit, L. Gabert, A. Penhoat, A. Durand, G. Pineau, F. Joffre, A. Géloën, C. Vaysse, F. Laugerette, and M.-C. Michalski. 2016. Dietary emulsifiers from milk and soybean differently impact adiposity and inflammation in association with modulation of colonic goblet cells in high-fat fed mice. Mol. Nutr. Food Res. 60:609-620. https://doi.org/10.1002/mnfr.201500703. 
Li, F., S.-L. An, Y. Zhou, Z.-K. Liang, Z.-J. Jiao, Y.-M. Jing, P. Wan, X.-J. Shi, and W.-L. Tan. 2011. Milk and dairy consumption and risk of bladder cancer: A meta-analysis. Urology 78:1298-1305. https://doi.org/10.1016/j.urology.2011.09.002.

Liapikos, T. A., S. Antonopoulou, S.-A. P. Karabina, D. C. Tsoukatos, C. A. Demopoulos, and A. D. Tselepis. 1994. Platelet-activating factor formation during oxidative modification of low-density lipoprotein when PAF-acetylhydrolase has been inactivated. Biochimica Biophysica Acta 1212:353-360.

Libby, P. 1995. Molecular bases of the acute coronary syndromes. Circulation 91:2844-2850. https://doi.org/10.1161/01.cir.91.11.2844.

Libby, P., P. M. Ridker, and A. Maseri. 2002. Inflammation and atherosclerosis. Circulation 105:1135-1143. https://doi.org/10.1161/ hc0902.104353.

Lock, A. L., and D. E. Bauman. 2004. Modifying milk fat composition of dairy cows to enhance fatty acids beneficial to human health. Lipids 39:1197-1206. https://doi.org/10.1007/s11745-004-1348-6.

Louie, J. C. Y., V. M. Flood, G. Burlutsky, A. M. Rangan, T. P. Gill, and P. Mitchell. 2013. Dairy consumption and the risk of 15-year cardiovascular disease mortality in a cohort of older Australians. Nutrients 5:441-454. https://doi.org/10.3390/nu5020441.

Mauerhofer, C., M. Philippova, O. V. Oskolkova, and V. N. Bochkov. 2016. Hormetic and anti-inflammatory properties of oxidized phospholipids. Mol. Aspects Med. 49:78-90. https://doi.org/10.1016/j. mam.2016.02.003.

Mazzei, J. C., H. Zhou, B. P. Brayfield, R. Hontecillas, J. BassaganyaRiera, and E. M. Schmelz. 2011. Suppression of intestinal inflammation and inflammation-driven colon cancer in mice by dietary sphingomyelin: Importance of peroxisome proliferator-activated receptor $\gamma$ expression. J. Nutr. Biochem. 22:1160-1171. https:// doi.org/10.1016/j.jnutbi0.2010.09.017.

McCowen, K. C., P. R. Ling, E. Decker, D. Djordjevic, R. Roberts, J. Coupland, and B. R. Bistrian. 2010. A simple method of supplementation of omega-3 polyunsaturated fatty acids use of fortified yogurt in healthy volunteers. Nutr. Clin. Pract. 25:641-645. https://doi.org/10.1177/0884533610385699.

Megalemou, K., E. Sioriki, R. Lordan, M. Dermiki, C. Nasopoulou, and I. Zabetakis. 2017. Evaluation of sensory and in vitro antithrombotic properties of traditional Greek yogurts derived from different types of milk. Heliyon 3: https://doi.org/10.1016/j. heliyon.2016.e00227.

Megson, I. L., P. D. Whitfield, and I. Zabetakis. 2016. Lipids and cardiovascular disease: Where does dietary intervention sit alongside statin therapy? Food Funct. https://doi.org/10.1039/c6f000024j.

Mele, M. C., G. Cannelli, G. Carta, L. Cordeddu, M. P. Melis, E. Murru, C. Stanton, and S. Banni. 2013. Metabolism of c9,t11conjugated linoleic acid (CLA) in humans. Prostaglandins Leukot. Essent. Fatty Acids 89:115-119. https://doi.org/10.1016/j. plefa.2013.05.005.

Mozaffarian, D., L. J. Appel, and L. Van Horn. 2011. Components of a cardioprotective diet new insights. Circulation 123:2870-2891. https://doi.org/10.1161/CIRCULATIONAHA.110.968735.

Mudau, M., A. Genis, A. Lochner, and H. Strijdom. 2012. Endothelial dysfunction: The early predictor of atherosclerosis. Cardiovasc. J. Afr. 23:222-231. https://doi.org/10.5830/CVJA-2011-068.

Nasopoulou, C., T. Smith, M. Detopoulou, C. Tsikrika, L. Papaharisis, D. Barkas, and I. Zabetakis. 2014. Structural elucidation of olive pomace fed sea bass (Dicentrarchus labrax) polar lipids with cardioprotective activities. Food Chem. 145:1097-1105. https://doi. org/10.1016/j.foodchem.2013.08.091.

Nasopoulou, C., and I. Zabetakis. 2015. Marine oils and inflammation. Page 179 in Marine Oils: From Sea to Pharmaceuticals. I. Zabetakis, ed. Nova Science Publishers, New York, NY.

Nathan, C. 2002. Points of control in inflammation. Nature 420:846852. https://doi.org/10.1038/nature01320.

Ness, A. R., G. D. Smith, and C. Hart. 2001. Milk, coronary heart disease and mortality. J. Epidemiol. Community Health 55:379-382.

Nestel, P. J., N. Mellett, S. Pally, G. Wong, C. K. Barlow, K. Croft, T. A. Mori, and P. J. Meikle. 2013. Effects of low-fat or full-fat fermented and non-fermented dairy foods on selected cardiovascu- lar biomarkers in overweight adults. Br. J. Nutr. 110:2242-2249. https://doi.org/10.1017/S0007114513001621.

Nestel, P. J., S. Pally, G. L. MacIntosh, M. A. Greeve, S. Middleton, J. Jowett, and P. J. Meikle. 2012. Circulating inflammatory and atherogenic biomarkers are not increased following single meals of dairy foods. Eur. J. Clin. Nutr. 66:25-31. https://doi.org/10.1038/ ejcn.2011.134.

Nilsson, Å. 2016. Role of sphingolipids in infant gut health and immunity. J. Pediatr. 173:S53-S59. https://doi.org/10.1016/j. jpeds.2016.02.076.

Norris, G. H., C. Jiang, J. Ryan, C. M. Porter, and C. N. Blesso. 2016. Milk sphingomyelin improves lipid metabolism and alters gut microbiota in high fat diet-fed mice. J. Nutr. Biochem. 30:93-101. https://doi.org/10.1016/j.jnutbi0.2015.12.003.

O'Keefe, J. H., and D. S. H. Bell. 2007. Postprandial hyperglycemia/hyperlipidemia (postprandial dysmetabolism) is a cardiovascular risk factor. Am. J. Cardiol. 100:899-904. https://doi. org/10.1016/j.amjcard.2007.03.107.

O'Keefe, J. H., N. M. Gheewala, and J. O. O'Keefe. 2008. Dietary strategies for improving post-prandial glucose, lipids, inflammation, and cardiovascular health. J. Am. Coll. Cardiol. 51:249-255. https://doi.org/10.1016/j.jacc.2007.10.016.

O'Sullivan, A., M. J. Gibney, and L. Brennan. 2011. Dietary intake patterns are reflected in metabolomic profiles: Potential role in dietary assessment studies. Am. J. Clin. Nutr. 93:314-321. https:// doi.org/10.3945/ajcn.110.000950.

Panagiotakos, D. B., C. H. Pitsavos, A. D. Zampelas, C. A. Chrysohoou, and C. I. Stefanadis. 2010. Dairy products consumption is associated with decreased levels of inflammatory markers related to cardiovascular disease in apparently healthy adults: The ATTICA study. J. Am. Coll. Nutr. 29:357-364. https://doi.org/10.10 80/07315724.2010.10719852.

Park, Y., J. M. Storkson, K. J. Albright, W. Liu, and M. W. Pariza. 1999. Evidence that the trans-10,cis-12 isomer of conjugated linoleic acid induces body composition changes in mice. Lipids 34:235-241. https://doi.org/10.1007/s11745-999-0358-8.

Patterson, E., S. C. Larsson, A. Wolk, and A. Åkesson. 2013. Association between dairy food consumption and risk of myocardial infarction in women differs by type of dairy food. J. Nutr. 143:74-79. https://doi.org/10.3945/jn.112.166330.

Peters, M. J. L., A. E. Voskuyl, N. Sattar, B. A. C. Dijkmans, Y. M. Smulders, and M. T. Nurmohamed. 2010. The interplay between inflammation, lipids and cardiovascular risk in rheumatoid arthritis: why ratios may be better. Int. J. Clin. Pract. 64:1440-1443. https://doi.org/10.1111/j.1742-1241.2009.02220.x.

Phan, T. T. Q., T. T. Le, D. Van de Walle, P. Van der Meeren, and K. Dewettinck. 2016. Combined effects of milk fat globule membrane polar lipids and protein concentrate on the stability of oil-inwater emulsions. Int. Dairy J. 52:42-49. https://doi.org/10.1016/j. idairyj.2015.08.003.

Pintus, S., E. Murru, G. Carta, L. Cordeddu, B. Batetta, S. Accossu, D. Pistis, S. Uda, M. Elena Ghiani, M. Mele, P. Secchiari, G. Almerighi, P. Pintus, and S. Banni. 2013. Sheep cheese naturally enriched in $\alpha$-linolenic, conjugated linoleic and vaccenic acids improves the lipid profile and reduces anandamide in the plasma of hypercholesterolaemic subjects. Br. J. Nutr. 109:1453-1462. https://doi.org/10.1017/S0007114512003224.

Plourde, M., S. Jew, S. C. Cunnane, and P. J. Jones. 2008. Conjugated linoleic acids: Why the discrepancy between animal and human studies? Nutr. Rev. 66:415-421. https://doi.org/10.1111/j.17534887.2008.00051.x.

Poutzalis, S., A. Anastasiadou, C. Nasopoulou, K. Megalemou, E. Sioriki, and I. Zabetakis. 2016. Evaluation of the in vitro antiatherogenic activities of goat milk and goat dairy products. Dairy Sci. Technol. 96:317. https://doi.org/10.1007/s13594-015-0266-x.

Praagman, J., J. W. Beulens, M. Alssema, P. L. Zock, A. J. Wanders, I. Sluijs, and Y. T. Van Der Schouw. 2016. The association between dietary saturated fatty acids and ischemic heart disease depends on the type and source of fatty acid in the European Prospective Investigation into Cancer and Nutrition-Netherlands 
cohort. Am. J. Clin. Nutr. 103:356-365. https://doi.org/10.3945/ ajcn.115.122671.

Prescott, S. M., G. A. Zimmerman, D. M. Stafforini, and T. M. McIntyre. 2000. Platelet-activating factor and related lipid mediators. Annu. Rev. Biochem. 69:419-445. https://doi.org/10.1146/ annurev.biochem.69.1.419.

Raff, M., T. Tholstrup, S. Basu, P. Nonboe, M. T. Sørensen, and E. M. Straarup. 2008. A diet rich in conjugated linoleic acid and butter increases lipid peroxidation but does not affect atherosclerotic, inflammatory, or diabetic risk markers in healthy young men. J. Nutr. 138:509-514.

Rashidi Pour Fard, N., M. Karimi, M. H. Baghaei, F. Haghighatdoost, M. H. Rouhani, A. Esmaillzadeh, and L. Azadbakht. 2015. Dairy consumption, cardiovascular risk factors and inflammation in elderly subjects. ARYA Atheroscler. 11:323-331.

Reuter, S., S. C. Gupta, M. M. Chaturvedi, and B. B. Aggarwal. 2010. Oxidative stress, inflammation, and cancer: How are they linked? Free Radic. Biol. Med. 49:1603-1616. https://doi.org/10.1016/j. freeradbiomed.2010.09.006.

Reynolds, C. M., and H. M. Roche. 2010. Conjugated linoleic acid and inflammatory cell signalling. Prostaglandins Leukot. Essent. Fatty Acids 82:199-204. https://doi.org/10.1016/j.plefa.2010.02.021.

Risérus, U., W. C. Willett, and F. B. Hu. 2009. Dietary fats and prevention of type 2 diabetes. Prog. Lipid Res. 48:44-51. https://doi. org/10.1016/j.plipres.2008.10.002.

Robertson, R. C., M. R. Gracia Mateo, M. N. O'Grady, F. Guihéneuf, D. B. Stengel, R. P. Ross, G. F. Fitzgerald, J. P. Kerry, and C. Stanton. 2016. An assessment of the techno-functional and sensory properties of yoghurt fortified with a lipid extract from the microalga Pavlova lutheri. Innov. Food Sci. Emerg. Technol. 37(Part B):237-246. https://doi.org/10.1016/j.ifset.2016.03.017.

Roche, H. M., E. Noone, C. Sewter, S. Mc Bennett, D. Savage, M. J. Gibney, S. O'Rahilly, and A. J. Vidal-Puig. 2002. Isomer-dependent metabolic effects of conjugated linoleic acid insights from molecular markers sterol regulatory element-binding protein-1c and LXRo. Diabetes 51:2037-2044.

Rodríguez-Alcalá, L. M., A. Villar-Tajadura, M. Juarez, and J. Fontecha. 2013. Commercial conjugated linoleic acid (CLA) fortified dairy products. Pages 173-184 in Handbook of Food Fortification and Health: From Concepts to Public Health Applications Vol. 1. V. R. Preedy, R. Srirajaskanthan, and V. B. Patel, ed. Springer New York, New York, NY.

Ross, R. 1999. Atherosclerosis - an inflammatory disease. N. Engl. J. Med. 340:115-126. https://doi.org/10.1056/ NE.JM199901143400207.

Salajegheh, A. 2016. Platelet-activating factor. Pages 253-260 in Angiogenesis in Health, Disease and Malignancy. Springer International Publishing, Cham, Switzerland.

Savoini, G., A. Agazzi, G. Invernizzi, D. Cattaneo, L. Pinotti, and A. Baldi. 2010. Polyunsaturated fatty acids and choline in dairy goats nutrition: Production and health benefits. Small Rumin. Res. 88:135-144. https://doi.org/10.1016/j.smallrumres.2009.12.021.

Schmelz, E. M., A. S. Bushnev, D. L. Dillehay, D. C. Liotta, and A. H. Merrill. Jr.1997. Suppression of aberrant colonic crypt foci by synthetic sphingomyelins with saturated or unsaturated sphingoid base backbones. Nutr. Cancer 28:81-85. https://doi. org $/ 10.1080 / 01635589709514556$

Schmelz, E. M., D. L. Dillehay, S. K. Webb, A. Reiter, J. Adams, and A. H. Merrill Jr.. 1996. Sphingomyelin consumption suppresses aberrant colonic crypt foci and increases the proportion of adenomas versus adenocarcinomas in CF1 mice treated with 1,2-dimethylhydrazine: Implications for dietary sphingolipids and colon carcinogenesis. Cancer Res. 56:4936-4941.

Schmelz, E. M., M. C. Sullards, D. L. Dillehay, and A. H. Merrill Jr.. 2000. Colonic cell proliferation and aberrant crypt foci formation are inhibited by dairy glycosphingolipids in 1, 2-dimethylhydrazine-treated CF1 mice. J. Nutr. 130:522-527.

Shingfield, K. J., Y. Chilliard, V. Toivonen, P. Kairenius, and D. I. Givens. 2008. Trans fatty acids and bioactive lipids in ruminant milk. Pages 3-65 in Bioactive Components of Milk. Springer Science+Business Media Inc., New York, NY.
Simon, K. W., L. Tait, F. Miller, C. Cao, K. P. Davy, T. LeRoith, and E. M. Schmelz. 2010. Suppression of breast xenograft growth and progression in nude mice: Implications for the use of orally administered sphingolipids as chemopreventive agents against breast cancer. Food Funct. 1:90-98. https://doi.org/10.1039/c0f000108b.

Simopoulos, A. P. 2016. An increase in the omega-6/omega-3 fatty acid ratio increases the risk for obesity. Nutrients 8:128 https:// doi.org/10.3390/nu8030128.

Simopoulos, A. P. 2002a. The importance of the ratio of omega-6/ omega-3 essential fatty acids. Biomed. Pharmacother. 56:365-379. https://doi.org/10.1016/S0753-3322(02)00253-6.

Simopoulos, A. P. 2002b. Omega-3 fatty acids in inflammation and autoimmune diseases. J. Am. Coll. Nutr. 21:495-505.

Simopoulos, A. P. 2004. Omega-6/omega-3 essential fatty acid ratio and chronic diseases. Food Rev. Int. 20:77-90. https://doi. org/10.1081/FRI-120028831.

Siurana, A., and S. Calsamiglia. 2016. A metaanalysis of feeding strategies to increase the content of conjugated linoleic acid (CLA) in dairy cattle milk and the impact on daily human consumption. Anim. Feed Sci. Technol. 217:13-26. https://doi.org/10.1016/j. anifeedsci.2016.04.013.

Sofi, F., A. Buccioni, F. Cesari, A. M. Gori, S. Minieri, L. Mannini, A. Casini, G. F. Gensini, R. Abbate, and M. Antongiovanni. 2010 Effects of a dairy product (pecorino cheese) naturally rich in cis9, trans-11 conjugated linoleic acid on lipid, inflammatory and haemorheological variables: A dietary intervention study. Nutr. Metab. Cardiovasc. Dis. 20:117-124. https://doi.org/10.1016/j. numecd.2009.03.004.

Sonestedt, E., E. Wirfält, P. Wallström, B. Gullberg, M. Orho-Melander, and B. Hedblad. 2011. Dairy products and its association with incidence of cardiovascular disease: The Malmö diet and cancer cohort. Eur. J. Epidemiol. 26:609-618. https://doi.org/10.1007/ s10654-011-9589-y.

Stancliffe, R. A., T. Thorpe, and M. B. Zemel. 2011. Dairy attenuates oxidative and inflammatory stress in metabolic syndrome. Am. J. Clin. Nutr. 94:422-430. https://doi.org/10.3945/ajcn.111.013342.

Sun, Q., J. Ma, H. Campos, and F. B. Hu. 2007. Plasma and erythrocyte biomarkers of dairy fat intake and risk of ischemic heart disease. Am. J. Clin. Nutr. 86:929-937.

Tholstrup, T., M. Raff, S. Basu, P. Nonboe, K. Sejrsen, and E. M. Straarup. 2006. Effects of butter high in ruminant trans and monounsaturated fatty acids on lipoproteins, incorporation of fatty acids into lipid classes, plasma C-reactive protein, oxidative stress, hemostatic variables, and insulin in healthy young men. Am. J. Clin. Nutr. 83:237-243.

Treede, I., A. Braun, R. Sparla, M. Kühnel, T. Giese, J. R. Turner, E. Anes, H. Kulaksiz, J. Füllekrug, and W. Stremmel. 2007. Anti-inflammatory effects of phosphatidylcholine. J. Biol. Chem. 282:27155-27164. https://doi.org/10.1074/jbc.M704408200.

Tricon, S., G. C. Burdge, E. L. Jones, J. J. Russell, S. El-Khazen, E. Moretti, W. L. Hall, A. B. Gerry, D. S. Leake, R. F. Grimble, C. M. Williams, P. C. Calder, and P. Yaqoob. 2006. Effects of dairy products naturally enriched with cis-9,trans- 11 conjugated linoleic acid on the blood lipid profile in healthy middle-aged men. Am. J. Clin. Nutr. 83:744-753.

Tselepis, A. D., and M. J. Chapman. 2002. Inflammation, bioactive lipids and atherosclerosis: Potential roles of a lipoprotein-associated phospholipase A2, platelet activating factor-acetylhydrolase. Atheroscler. Suppl. 3:57-68. https://doi.org/10.1016/S15675688(02)00045-4.

Tsorotioti, S. E., C. Nasopoulou, M. Detopoulou, E. Sioriki, C. A. Demopoulos, and I. Zabetakis. 2014. In vitro anti-atherogenic properties of traditional Greek cheese lipid fractions. Dairy Sci. Technol. 94:269-281. https://doi.org/10.1007/s13594-014-0161-x.

van Aerde, M. A., S. S. Soedamah-Muthu, J. M. Geleijnse, M. B. Snijder, G. Nijpels, C. D. Stehouwer, and J. M. Dekker. 2013. Dairy intake in relation to cardiovascular disease mortality and all-cause mortality: The Hoorn study. Eur. J. Nutr. 52:609-616. https://doi. org/10.1007/s00394-012-0363-z.

Van Eldik, L. J., M. C. Carrillo, P. E. Cole, D. Feuerbach, B. D. Greenberg, J. A. Hendrix, M. Kennedy, N. Kozauer, R. A. Margo- 
lin, J. L. Molinuevo, R. Mueller, R. M. Ransohoff, D. M. Wilcock, L. Bain, and K. Bales. 2016. The roles of inflammation and immune mechanisms in Alzheimer's disease. Alzheimers Dement (N Y) 2:99-109. https://doi.org/10.1016/j.trci.2016.05.001.

van Meijl, L. E., and R. P. Mensink. 2011. Low-fat dairy consumption reduces systolic blood pressure, but does not improve other metabolic risk parameters in overweight and obese subjects. Nutr. Metab. Cardiovasc. Dis. 21:355-361. https://doi.org/10.1016/j. numecd.2009.10.008.

van Meijl, L. E. C., and R. P. Mensink. 2010. Effects of low-fat dairy consumption on markers of low-grade systemic inflammation and endothelial function in overweight and obese subjects: An intervention study. Br. J. Nutr. 104:1523-1527. https://doi.org/10.1017/ S0007114510002515.

Wall, R., R. P. Ross, G. F. Fitzgerald, and C. Stanton. 2010. Fatty acids from fish: The anti-inflammatory potential of long-chain omega-3 fatty acids. Nutr. Rev. 68:280-289. https://doi.org/10.1111/ j.1753-4887.2010.00287.x.

Wang, C., H. Yatsuya, K. Tamakoshi, H. Iso, and A. Tamakoshi. 2015. Milk drinking and mortality: Findings from the Japan collaborative cohort study. J. Epidemiol. 25:66-73. https://doi.org/10.2188/ jea.JE20140081.

Wennersberg, M. H., A. Smedman, A. M. Turpeinen, K. Retterstøl, S. Tengblad, E. Lipre, A. Aro, P. Mutanen, I. Seljeflot, and S. Basu.
2009. Dairy products and metabolic effects in overweight men and women: Results from a 6-mo intervention study. Am. J. Clin. Nutr. 90:960-968. https://doi.org/10.3945/ajcn.2009.27664.

Whigham, L. D., A. C. Watras, and D. A. Schoeller. 2007. Efficacy of conjugated linoleic acid for reducing fat mass: A meta-analysis in humans. Am. J. Clin. Nutr. 85:1203-1211.

Yaqoob, P. 2015. Effects of conjugated linoleic acids on human health. Pages 749-795 in Functional Foods, Nutraceuticals and Natural Products. D. A. Vattem and V. Maitin, ed. DEStech Publications Inc., Lancaster, PA.

Yeganeh, A., C. G. Taylor, J. Poole, L. Tworek, and P. Zahradka. 2016. Trans10, cis12 conjugated linoleic acid inhibits 3T3-L1 adipocyte adipogenesis by elevating $\beta$-catenin levels. Biochim. Biophys. Acta 1861:363-370. https://doi.org/10.1016/j.bbalip.2016.01.004.

Zabetakis, I. 2013. Food security and cardioprotection: The polar lipid link. J. Food Sci. 78:R1101-R1104. https://doi.org/10.1111/17503841.12194

Zemel, M. B., X. Sun, T. Sobhani, and B. Wilson. 2010. Effects of dairy compared with soy on oxidative and inflammatory stress in overweight and obese subjects. Am. J. Clin. Nutr. 91:16-22. https://doi.org/10.3945/ajcn.2009.28468.

Zheng, H., M. R. Clausen, T. K. Dalsgaard, and H. C. Bertram. 2015. Metabolomics to explore impact of dairy intake. Nutrients 7:48754896. https://doi.org/10.3390/nu7064875. 